\title{
Locus Of Control Internal dan Stres Kerja Pada Anggota Polisi Reserse Kriminal
}

\author{
Layyina Hafna', Eka Dian Aprilia ${ }^{2}$ \\ Program Studi Psikologi Universitas Syiah Kuala, \\ e-mail: ${ }^{1}$ laynahafna@gmail.com, ${ }^{2}$ eka.aprilia@unsyiah.ac.id
}

\begin{abstract}
Abstrak
Tugas sebagai seorang reserse criminal sangat rentan terhadap stres karena memiliki resiko dan beban kerja yang berat. Stres kerja merupakan suatu kondisi ketegangan yang menciptakan adanya ketidakseimbangan fisik dan psikis yang memengaruhi emosi, proses berpikir dan kondisi individu di lingkungan kerja. Salah satu faktor yang memengaruhi stres kerja adalah locus of control internal. Individu dengan locus of control internal percaya bahwa keberhasilan atau kegagalan tergantung pada dirinya. Penelitian ini bertujuan untuk meneliti hubungan antara locus of control internal dengan stres kerja pada anggota polisi khususnya bagian reserse kriminal. Teknik pengambilan sampel yang digunakan dalam penelitian ini bincidental sampling dengan jumlah 43 sampel yang terdiri dari direktorat reserse kriminal umum dan direktorat reserse kriminal khusus. Alat ukur yang digunakan dalam penelitian ini adalah skala adaptasi internal-eksternal locus of control dari Rotters (1966) dan skala adaptasi stres kerja dari House, McMichael, Wells, Kaplan, dan Landerman (1979). Hasil analisis data menggunakan teknik korelasi spearman menunjukkan koefisien korelasi $(r)$ sebesar 0,464 dengan nilai $p=0,001(p<0,05)$. Hipotesis diterima sehingga dapat disimpulkan bahwa terdapat hubungan positif dan signifikan antara locus of control internal dan stres kerja pada polisi reserse kriminal.
\end{abstract}

Kata Kunci: Locus of control, Stres kerja, Polisi reserse kriminal

\section{Locus Of Control Internal and Occupational Stress on Police Crime Detectives}

\begin{abstract}
To be a criminal detectives is very susceptible to stress as a risk and a heavy workload.. Occupational stress is a condition of tension that creates an imbalance in the physical and psychological influence emotions, thought processes and conditions of individuals in the work environment. One of the factors that affect occcupational stress is an internal locus of control. Individuals with an internal locus of control believe that success or failure depends on him. This study aims to investigate the relationship between internal locus of control with work stress on police criminal detectives. The sampling technique used in this study incidental sampling with a sample consisting of 43 directorates general and directorates criminal detectives specialized criminal detectives. Measuring instrument used in this study consists of the scale internal-external locus of control adapt from the Rotters (1966) and the scale of occupational stress adaptation of the House, McMichael, Wells, Kaplan, and Landerman (1979). The results of data analysis using Spearman correlation technique showed a correlation coefficient $(r)$ of 0.464 with $p=0.001(p<0.05)$. The hypothesis is accepted so it can be concluded that there is a positive and significant relationship between internal locus of control and occupational stress on police criminal detectives.
\end{abstract}

Keywords: Locus of control, Occupational stress, Police criminal detectives 


\section{Pendahuluan}

Kepolisian Negara Republik Indonesia (Polri) merupakan suatu lembaga yang mendapatkan tugas dan wewenangnya berdasarkan sistem ketatanegaraan Indonesia untuk menjaga keamanan negara dan menegakkan hukum yang berlaku dalam wilayahNegaraRepublik Indonesia. Organisasi Polri disusun secara berjenjang dari tingkat pusat sampai tingkat daerah berdasarkan daerah hukum sesuai dengan ketentuan peraturan perundang-undangan. Salah satu organisasi Polri ditingkat daerah yaitu Polda (Peraturan Presiden Nomor 52 tahun 2010). Polda bertugas menyelenggarakan tugas Polri pada tingkat provinsi termasuk di Aceh.

Polda Aceh membawahi kepolisian tingkat kabupaten kota dan kecamatan yang ada di Aceh. Polda dalam melaksanakan tugas pokok khususnya dalam hal pelaksanaan penyidikan dan penyelidikan dibantu oleh subbagian pelaksana tugas pokok yaitu Direktorat reserse kriminal umum dan Direktorat reserse kriminal khusus. Direktorat reserse kriminal menangani kasus yang memiliki efek besar, kasus yang menjadi perhatian publik, dan kasus-kasus yang memiliki wilayah hukum lebih luas, kasus yang pengungkapannya susah, kasus tindak pidana mencakup beberapa kabupaten (UndangUndang Dasar nomor 2 tahun 2002).

Setiap kasus tindak pidana tertentu memilikiwaktu penyelesaian kasus selama tiga bulan, sedangkan kasus tindak pidana korupsi selama enam bulan. Hal tersebutmenunjukkan bahwa setiap penyidik menangani lebih dari satu kasus dengan waktu yang telah ditentukan berdasarkan jenis kasus. Tugastugas pokok polisi reserse kriminal antara lain yaitu melakukan pemeriksaan pelaku dan saksi, menyiapkan berkas, menyiapkan berita acara, menyusun administrasi penyidikan, membuat berita acara sumpah, tes laporan polisi, membuat rangkuman serta surat-surat administrasi (Undang-Undang Dasar nomor 2 tahun 2002). Selain itu, polisi memiliki tugas rutin yang berbeda dengan dari pekerjaan lainnya, seperti polisi harus selalu siaga untuk menghindari dan mencegah terjadinya ancaman atau bahaya yang merugikan untuk mewujudkan ketertiban dan keamanan masyarakat walaupun di hari libur (Kunarto, 1999). Menurut (Dodik \& Astuti, 2012) banyaknya tugas dan kasus yang harus ditangani membuat polisi reserse kriminal harus bekerja selama 24 jam saat menangani kasus yang seharusnya polisi reserse kriminal bekerja selama 8 jam, sehingga waktu kerja polisi reserse kriminal 16 jam lebih banyak dibandingkan dengan pekerjaan biasanya.

Pelaksanaan tugas sebagai polisi tidak hanya berhubungan dengan pelaku tindak kriminal, namun juga dengan korban, keluarga korban, rekan sesama polisi, berhubungan dengan kejaksaan dan atasan, peraturan ditempat kerja, beban kerja yang kadangkala dinilai tidak sesuai dengan konflik fisik, psikis dan emosional. Tugas-tugas yang dijalankan oleh pihak kepolisian dapat menimbulkan ketegangan sehingga dapat memicu potensi stres yang tinggi saat bekerja karena tugasnya yang cukup berat dan beban tugasnya yang tinggi (Jorgensen \& Rottman, 2008).

Menurut Saragih dan Rizkiyani (2012) bahwa kondisi kerja yang memiliki resiko tinggi dan berbahaya dapat menyebabkan terjadinya stres. Stres dapat dialami oleh siapapun dan termasuk pada individu yang bekerja seperti karyawan, guru, perawat, dokter, termasuk polisi juga mengalami stres dalam melaksanakan tugas (Anoraga, 2005). Polisi merupakan salah satu pekerjaan yang memiliki resiko tinggi terhadap timbulnya stres, hal ini dikarenakan polisi mendapat tekanan saat melaksanakan tugas (Sarafino, 2011). Hal ini senada dengan pernyataan yang diungkapkan oleh Dodik dan Astuti (2012) bahwa stres dapat muncul di lingkungan kerja polisi karena polisi mendapat tekanan saat melaksanakan tugas yang dituntut agar selalu memiliki disiplin yang tinggi, patuh pada peraturan yang berlaku dan tunduk pada perintah atasan, cepat dan tanggap mengatasi segala permasalahan yang ada.

Tuntutan tugas dalam menyelesaikan pekerjaan dari suatu organisasi merupakan sumber stres lain bagi polisi sehingga karakteristik kepribadian memengaruhi 
dalam merespon suatu kejadian yang dialami termasuk bagaimana menghadapi sumber stres. Karakter kepribadian yang berpengaruh terhadap munculnya stres yaitu locus of control (Rahim, 1997). Locus of control merupakan keyakinan individu terhadap sumber peristiwa dalam hidupnya (Rotter, 1966). Individu yang memiliki locus of control internal cenderung dapat mengelola stres dengan baik, maka kinerja polisi akan menjadi lebih efektif (Samreen dan Zubair, 2013). Samreen \& Zubair (2013) menambahkan polisi yang memiliki locus of controlinternal akan berusaha mengoptimalkan segala kemampuan yang dimiliki, pemahaman, serta pengalamannya yang kemudian diaplikasikan pada saat bekerja supaya dapat menyelesaikan tugas dengan baik, cepat, dan tepat sehingga sumber yang dapat menyebabkan stres dapat diatasi

Stres kerja yang dialami oleh individu yang memiliki locus of controlinternal membuat individu lebih didominasi oleh faktor-faktor yang ada di dalam dirinya sehingga usaha yang dikerahkan untuk melaksanakan tugas dan menyelesaikan kasus menjadi lebih besar, serta bersedia mengandalkan kemampuannya untuk bekerja sama dengan rekan kerja dan melaksanakan tugas sesuai dengan aturan, dan memandang peraturan itu sesuai dengan karakteristik dirinya. Individu juga mau belajar dari pengalaman ketika melakukan kesalahan atau kekeliruan dalam bertugas karena pada dasarnya individu ini mempersepsikan aturan itu memiliki tujuan yang baik. Perilaku yang akan dimunculkan oleh individu dengan locus of control internal yaitu bertanggung jawab, mampu mengendalikan diri, dan sadar akan konsekuensi atas setiap tingkah lakunya saat menyelesaikan tugasnya (Goyzman, 2009).

Penelitian yang dilakukan oleh Lu, Wu dan Cooper (1999) menunjukkan bahwa terlihat lebih sedikit stres pada individu yang memiliki locus of control dikarenakan individu tersebut mampu mengendalikan sumber stres. Keyakinan individu akan kemampuannya menyelesaikan masalah dan bertanggung jawab atas apa yang terjadi dalam hidupnya sehingga ancaman terhadap stres kerja lebih sedikit cenderung dialami oleh individu yang memiliki locus of control internal (O'brien, 1984).

\section{Metode}

Penelitian ini merupakan penelitian kuantitatif yang populasinya ialah Polisi reserse kriminal Polda Aceh. Pengambilan sampel dilakukan dengan cara non-probability sampling yaitu teknik incidental sampling. Teknik ini menentukan sampel berdasarkan kebetulan, yaitu siapa saja yang secara kebetulan atau insidental bertemu dengan peneliti dapat digunakan sebagai sampel, bila dipandang orang yang kebetulan ditemui itu cocok sebagai sumber data. Kriteria sampel penelitian adalah polisi reserse kriminal Polda Aceh, tidak sedang bertugas di luar kota, dan bersedia menjadi responden. Jumlah populasi dalam penelitian ini adalah 140 polisi. Pengambilan jumlah sampel mengacu pada tabel besar populasi dan sampel menurut Issac dan Michael dengan taraf kepercayaan 95\%, sehingga jumlah sampel adalah 119 polisi, namun di lapangan peneliti hanya menjumpai 43 orang polisi dengan kisaran usia 25-40 tahun yang bersedia menjadi responden.

\section{Pengukuran}

Alat ukur yang digunakan dalam penelitian ini adalah Skala Rotter's Locus of Control Scale yang diadaptasi dari Rotter (1966) yang terdiri dari 23 aitem internal dan eksternal dan 6 aitem pengecoh dan Skala Stres Kerja yang diadaptasi dari House, dkk (1979). Pada Skala Rotter's Locus of Control Scale skor penilaian bergerak dari 0 (nol) dan 1 (satu) sedangkan pada Skala Stres Kerja penilaian bergerak dari 0 (nol) sampai 4 (empat). Aitem pada kedua skala tersebut hanya terdiri dari pernyataan favorable.

\section{Analisis Data}

Teknik analisis data yang digunakan untuk menguji hipotesis yaitu teknik analisis korelasi Spearman. Metode ini digunakan untuk membuktikan hubungan antara locus of control internal dengan stres kerja pada polisi reserse kriminal Polda Aceh. 


\section{Hasil}

Deskripsi data locus of control

Deskripsi data hasil penelitian adalah sebagai berikut berikut :

Tabel 1. Deskripsi Data Penelitian Rotter's Locus of Control Scale

\begin{tabular}{|c|c|c|c|c|c|c|c|c|}
\hline \multirow[b]{2}{*}{ Tabel } & \multicolumn{4}{|c|}{ Data Hipotetik } & \multicolumn{4}{|c|}{ Data Empirik } \\
\hline & Xmaks & $\begin{array}{l}\mathrm{Xmi} \\
\mathrm{n}\end{array}$ & $\begin{array}{l}\text { Mea } \\
\mathrm{n}\end{array}$ & SD & $\begin{array}{l}\text { Xmak } \\
\text { s }\end{array}$ & $\begin{array}{l}\mathrm{Xmi} \\
\mathrm{n}\end{array}$ & $\begin{array}{l}\text { Mea } \\
\mathrm{n}\end{array}$ & SD \\
\hline $\begin{array}{l}\text { Locus of } \\
\text { control }\end{array}$ & 23 & 0 & 11,5 & 3,8 & 11 & 4 & 8,95 & $\begin{array}{l}1,8 \\
7\end{array}$ \\
\hline
\end{tabular}

Keterangan Rumus Skor Hipotetik :

1. Skor minimal (Xmin) adalah hasil perkalian jumlah butir skala dengan nilai terendah dari pembobotan pilihan jawaban.

2. Skor maksimal (Xmaks) adalah hasil perkalian jumlah butir skala dengan nilai tertinggi dari pembobotan pilihan jawaban.

3. Mean $(\mu)$ dengan rumus $\mu=$ (skor max + skor $\min ) / 2$

4. Standar deviasi $(\sigma)$ dengan rumus $\sigma=($ skor $\max -$ skor $\min ) / 6$

Deskripsi data Skala Stres Kerja

Tabel 2. Deskripsi Data Penelitian Skala Stres Kerja

\begin{tabular}{lllllllll}
\hline Variabel & \multicolumn{2}{l}{ Data Hipotetik } & \multicolumn{6}{c}{ Data Empirik } \\
& $\begin{array}{llllllll}\text { Xmak } \\
\end{array}$ & $\mathbf{X m i n}$ & $\begin{array}{l}\text { Mea } \\
\mathbf{n}\end{array}$ & SD & $\begin{array}{l}\text { Xmak } \\
\mathbf{s}\end{array}$ & $\begin{array}{l}\text { Xmi } \\
\mathbf{n}\end{array}$ & $\begin{array}{l}\text { Mea } \\
\mathbf{n}\end{array}$ & SD \\
\hline $\begin{array}{l}\text { Stres } \\
\text { kerja }\end{array}$ & 60 & 0 & 30 & 10 & 30 & 8 & $\begin{array}{l}21.4 \\
0\end{array}$ & $\begin{array}{l}5,7 \\
6\end{array}$
\end{tabular}

Keterangan Rumus Skor Hipotetik :

1. Skor minimal (Xmin) adalah hasil perkalian jumlah butir skala dengan nilai terendah dari pembobotan pilihan jawaban.

2. Skor maksimal (Xmaks) adalah hasil perkalian jumlah butir skala dengan nilai tertinggi dari pembobotan pilihan jawaban.

3. Mean $(\mu)$ dengan rumus $\mu=($ skor max + skor $\min ) / 2$

4. Standar deviasi $(\sigma)$ dengan rumus $\sigma=($ skor $\max -$ skor $\min ) / 6$

Pembagian kategori sampel yang digunakan oleh peneliti yaitu Pertimbangan Eror Standar dalam Pengukuran. Menurut Azwar (2013) pertimbangan eror standar dalam pengukuran adalah deviasi standar eror $\left(S_{e}\right)$ yang menunjukkan besarnya variasi eror $\left(S_{x}\right)$ pengukuran pada sekelompok subjek. Deskripsi data hasil penelitian tersebut dapat dijadikan batasan dalam pengkategorian sampel penelitian yang terdiri dari dua kategori, yaitu rendah dan tinggi.
Peneliti menggunakan taraf signifikansi 95\% sehingga didapatkan:

$$
\begin{aligned}
& X \pm z_{\alpha / 2}\left(s_{\mathrm{e}}\right)=X \pm z_{0,05 / 2}(3,316) \\
&=X \pm z_{0,25}(3,316) \\
&=X \pm 0,97(3,316) \\
&=X \pm 3,13 \text { atau } \\
& \text { dibulatkan menjadi } X \pm 3 \\
& \text { Mean }=75 / 2=38
\end{aligned}
$$

Kategorisasi ini membagi skor subjek ke dalam dua kategori yaitu skor tinggi dan skor rendah. Kategorisasi ini menggunakan nilai mean atau harga rata-rata sebagai nilai batas 
kategori. Skor yang lebih besar daripada mean diinterpretasikan sebagai tinggi dan skor yang berada di bawah mean diinterpretasikan rendah, sedangkan skor yang sama dengan mean diinterpretasikan tidak terkategorisasi (Azwar, 2013).

Tabel 3. Kategorisasi stres kerja

\begin{tabular}{llll}
\hline Skor & Kategori & Jumlah & Persentase \\
\hline $\mathrm{X}<35$ & Rendah & 43 & $100 \%$ \\
$36 \leq \mathrm{X}<37$ & Tidak & 0 & $0 \%$ \\
$38<\mathrm{X}$ & Terkategorisasi & & \\
\hline
\end{tabular}

Uji hipotesis yang dilakukan dalam penelitian ini menggunakan analisis ststistik parametrik dengan teknik korelasi Spearman Correlation. Halini dikarenakan hasil salah satu uji asumsi yaitu uji normalitas pada penelitian ini tidak terpenuhi.Hasil analisis menunjukkan nilai signifikansi $p=0,001<0,05$. Hal tersebut menunjukkan bahwa hipotesis penelitian ini diterima yaitu terdapat hubungan antara locuf of control internal dengan stres kerja pada anggota polisi reserse kriminal.

Penelitian ini memperoleh koefisien korelasi sebesar 0,464. Nilai tersebut menunjukkan bahwa terdapat antara locus of controlinternaldenganstreskerja. Berdasarkan hubungan tersebut dapat diketahui bahwa polisi reserse kriminal memiliki locus of control internal sehingga stres kerjanya rendah. Selain melakukan uji asumsi dan uji hipotesis, peneliti juga melakukan analisis sumbangan efektif dari kedua variabel menggunakan Measures of Association. Berdasarkan analisis tersebutmenunjukkan nilai R Square $\left(R^{2}\right)$ sebesar 0,215 yang artinya terdapat $21,5 \%$ sumbangan efektif locus of control internal terhadap stres kerja. Sementara $78,5 \%$ dipengaruhi oleh faktor lainnya.

\section{Pembahasan}

Penelitian ini bertujuan untuk mengetahui apakah ada hubungan locus of control internal danstres kerja pada polisi reserse kriminal Polda Aceh. Hasil penelitian ini menunjukkan bahwa locus of control internal memiliki hubungan dengan stres kerja pada polisi reserse kriminal. Hubungan ini menunjukkan polisi yang memiliki locus of control internal memiliki tingkat stres kerja yang rendah. Hal tersebut dibuktikan dengan hasil perhitungan statistik dengan koefisien korelasinya sebesar 0,464 dan nilai signifikansi sebesar 0,001 $(p<0,05)$ sehingga dapat dikatakan bahwa hipotesis pada penelitian ini diterima.

Penelitian dengan variabel locus of control dan stres kerja ini pernah dilakukan oleh Makikama, KairupandanTucunan (2015) meskipun dengan sampel yang berbeda. Hasil penelitian menunjukkan bahwa terdapat hubungan antara locus of control dengan stres kerja pada perawat. Hasil penelitian ini didukung oleh beberapa penelitian terdahulu, salah satunya adalah penelitian yang dilakukan oleh Anderson (2002) yang memaparkan bahwa seseorang yang dikendalikan oleh kekuatan sendiri atau memiliki locus of control internal ditemukan kurang merasa tertekan, rendahnya tingkat stres, dan menunjukkan perilaku yang lebih berorientasi pada pekerjaan daripada perilaku yang berorientasi pada emosi. Selain itu, perilaku yang berorientasi pada pekerjaan dari individu yang memiliki locus of control internal diasosiasikan dengan prestasi yang lebih baik.

Hal yang sama juga terjadi pada penelitian yang dilakukan oleh Rahim (1997) bahwa variabel locus of control internal dapat digunakan sebagai prediktor dengan arah korelasi negatif untuk memprediksi tingkat stres kerja. Jorgensen dan Rottman (2008) juga menjelaskan bahwa locus of control internal merupakan salah satu indikator penting dalam mengatasi stres kerja pada polisi.

Sama halnya dengan hasil penelitian yang dilakukan oleh Goyzman (2012), locus of 
control internal merupakan faktor yang dapat melindungi diri dari pengalaman-pengalaman yang dapat menyebabkan stres kerja. Ketika individu tidak mampu untuk mengembalikan keyakinan dirinya saat mengalami kegagalan dalam rangka pemenuhan tuntutan kerja, maka individu akan mudah untuk merasakan stres dan depresi. Hal serupa juga dinyatakan oleh Bernardi (2003) bahwa locus of control internaldapat meningkatkan pencapaian diri yang kemudian mengakibatkan rendahnya stres dan sebaliknya. Locus of control internal memengaruhi bagaimana seseorang merasakan, berfikir, memotivasi diri dan berperilaku (Lu, Wu, \& Cooper, 1999).

Hal yang sama juga terjadi pada penelitian yang dilakukan oleh Sujana dan Wulan (1994), yang mengemukakan bahwa karyawan yang memiliki/ocus of contro/internal akan lebih aktif berusaha keras, berprestasi, penuh kekuatan, tidak tergantung dan efektif. Karyawan demikian memiliki sifat lebih mandiri dan lebih ulet serta memiliki daya tahan yang lebih kuat terutama dalam menghadapi kegagalan, khususnya dalam dunia kerja. Hal inilah yang menyebabkan seseorang dengan locus of control internal lebih mampu menghadapi stres kerja yang dialaminya. Individu yang memiliki locus of control internal yang akan memiliki tingkat stres yang lebih rendah karena individu tersebut memiliki daya tahan dan keefektifan dalam menghadapi dan menyikapi datangnya stressor-stressor kerja (Wilski, Chmielewski,\&Tomczak, 2015).

Karimi dan Alipour (2011) menyatakan bahwa pengurangan dan pengendalian stres kerja pada karyawan merupakan hal yang penting untuk dilakukan perusahaan mengingat stress kerja dapat menimbulkan dampak negatif seperti absensi, produktivitas menurun, kepuasan yang rendah dan penyakit baik fisik maupun psikologis. Menurut Karimi dan Alipour (2011), locus of control internal merupakan faktor efektif yang dapat mengurangi stres kerja, selain faktor kepuasan kerja, promosi, harga diri, peningkatan gaji dan kualitas hidup karyawan.

Hasil analisis data secara deskriptif menunjukkan bahwa subjek dalam penelitian ini memiliki locus of control internal dan stres kerja yang berada pada kategori rendah. Hal ini sejalan dengan penelitian yang dilakukan oleh Lozano (2015) bahwa individu yang lebih berpengalaman cenderung memiliki locus of control internal. Salah satu penelitian terdahulu dari Anderson (1997) membuktikan bahwa individu berpengalaman (bekerja lebih dari lima tahun) memiliki locus of control internal.

Penelitianinimenghasilkansumbangan efektif yang ditunjukkan oleh nilai $\mathrm{R}$ Square $\left(R^{2}\right)$ sebesar 0, 21,5 dengan persentase $21 \%$ artinya locus of control internalmampu memengaruhi stres kerja sehingga bisa dikatakan bahwa terdapat hubungan antara locus of control internaldengan stres kerja pada polisi reserse kriminal Polda Aceh. Namun sumbangan efektif dengan persantese $21 \%$ tergolong lemah bisa disebabkan oleh pengaruh faktor lain yang tidak terlihat dalam penelitian ini. Faktor lain yang mungkin memengaruhi stres kerja adalah bentukbentuk fisik dari tempat kerja seperti beban kerja yang sulit dan berlebihan (Robbins dan Judge, 2013). Hal lain juga diungkapkan oleh Robbins dan Judge (2013) yaitu tekanan dan sikap pimpinan yang kurang adil dan kurang wajar, waktu dan peralatan kerja yang kurang memadai, konflik antar pribadi dengan pimpinan atau kelompok kerja.

\section{Kesimpulan}

Penelitian ini bertujuan untuk mengetahui hubungan antara locus of control internal dengan stres kerja pada polisi reserse kriminal. Hasil penelitian ini menunjukkan bahwa terdapat hubungan positif dan signifikan antara locus of control internal dengan stres kerja pada polisi reserse kriminal Polda Aceh. Hal tersebut mengindikasikan bahwa individu yang memiliki locus of control internal memiliki stres kerja yang rendah. Berdasarkan sumbangan efektif locus of control internal terhadap stres kerja pada polisi reserse kriminal Polda Aceh sebesar $21,5 \%$, hal ini menjelaskan peran locus of control internalmemengaruhi stres kerja pada polisi reserse kriminal Polda Aceh. 


\section{Daftar Pustaka}

Anderson. (2002). An international journal of police strategies \& management. Journal of Applied Psychology, 25, 399420

Bernardi, R. A. (2012). The relationship among locus of control perseption of stress and performance. Journal of applied bussiness research, 13(4), 1-8.

Dodik. A. A., \& Astuti. K. (2012). Hubungan antara kepribadian hardiness dengan stres kerja pada anggota polri bagian operasional di polresta Yogyakarta. Jurnal psikologi, 10(1), 37-48

Goyzman, J. (2010). The influence of locus of control and stress on performance. Journal of Applied Psychology, 62, 4, 128-144

Greenberg, J.S., 2004. Comprehensive stress management. 8th ed. New York: McGraw-Hill.

Jorgensen. L. I., \& Rothmann. S. (2008). Occupational stress, ill health and organisational commitmen of members of the south African police service in the north west province. Journal psychology, 21(2), 1-15

Karimi, R., A. F. (2011). Reduce job stress in organizations: role of locus of control. International Journal of Business and Social Science. 2 (18), 232-236

Lozano, C. (2015). A functional-contextualist account of locus of control: Generalized control expectancies as derived relational responding. Journal of Contextual Behavior Science. 4 .312323

O'Brien M, B. E,\& Hegney D. The influence of psychological factors on breastfeeding duration. Journal Of Advance Nursing. 63 397-408.

Peraturan Kapolri Nomor 22 tahun 2010. Susunan organisasi dan tata kerja pada Tingkat Kepolisian Daerah. Indonesia: Mabes Polri.

Peraturan presiden (Perpres) Nomor 52 tahun 2010. Susunan organisasi dan tata kepolisian negara republik Indonesia. Retrieved 17 januari 2016 melalui http://
www.polri.go.id/unduh.php?f=UGVycHJlcy BOb21vciAIMiBUYWh1biAyMDwLnBkZg==

Rahim. M. A. (1997). Relationships of stress, locus of control, and social support to Psychiatric symptoms and Propensity to leave a job: a field Study with managers. Journal of business and psychology, 232-236

Robbin, S. P., \& Judge, T. A. (2013). Organizational behavior. Upper Sadle River, NJ: Pearson Education Inc

Rotter, J.B.(1966). Generalized expectancies for internal versus external control of reinforcement, psychological monographs, 80 (1). 19-66.

Samreen. H., \& Zubair. A. (2013). Locus of Control and Death Anxiety among Police personel. Journal Psychology, 28(2), 261-275

Sarafino, E. P., \& Smith, T. W. (2012). Health Psychology: Biopsychosocial Interactions. John Wiley \& Sons Inc.

Sujana, Y.E. \& Wulan, R. 1994. Hubungan antara Kecenderungan Pusat Kendali dengan Intensi Menyontek. Jurnal Psikologi. 21(2), 1-8.

Undang-Undang Republik Indonesia Nomor 2 tahun 2002 Tentang Kepolisian Negara Republik Indonesia. 